\title{
Rethinking and Reconceptualizing Economics to Eradicate Inequality and Poverty
}

\author{
Jack Reardon \\ Professor of Economics, Hamline University, Minnesota, USA
}

\begin{abstract}
Poverty in inner cities and rural areas of 'rich' America is shocking for many which remains invisible to policymakers. It is clear that if pervasive and intransigent poverty can exist in America, it can exist anywhere. This paper focuses on actualizing Asad Zaman's (2018) suggestions in order to move forward so we can create and implement sustainability. It also tries to integrate his suggestions into the broader movement to Rethink and Reconceptualize Economics in order to effectuate a broadbased policy for the eradication of inequality and poverty.
\end{abstract}

Keywords: Inequality, Poverty alleviation, Multi-dimensional poverty, Pluralism, Rethinking economics, Sustainability.

KAUJIE Classification: N2, N3, N4, N7.

\section{Introduction}

In his book History of Islamic Economic Thought, Islahi (2014) writes,

We should pave the way for exchange and dialogue between the West and East on equal footing. Indeed, through dialogue on the basis of tolerance and mutual respect, the shared values become more familiar than those that distinguish and divide (p. 101).

I agree: such dialogue is essential to understanding our world and developing effective solutions to our problems. I am honored to participate in this important discussion forum, and I thank Islahi for his kind invitation.
It is a double honor for me to respond to Asad Zaman; not only do I admire his erudition and passion for justice, but I have learned from him so much about Islam and Islamic Economics. As founding editor of the International Journal of Pluralism and Economics, I asked Asad to co-edit a special issue on Islamic economics. In the introduction to the special issue we wrote, "we believe that Islamic economics offers a rich repository of ideas and concepts originally developed as solutions to real practical problems, and can elucidate our current predicament and help conceptualize solutions" (Zaman \& Reardon, 2015, p. 317). 
As a citizen of the USA, I didn't have to venture far to experience poverty first hand: it was ubiquitous in inner cities and rural areas. An eye-opener for many Americans was Michael Harrington's book, The Other America, which shocked many out of complacency. The book's title underscored Harrington's thesis that beneath the veneer of opulence, another America existed, mired in hopeless poverty, invisible to policymakers, and with little hope for the future. After reading Harrington's book, the reader is unsure which America is the 'other' America - rich or poor. It is also clear that if pervasive and intransigent poverty can exist in America, it can exist anywhere ${ }^{(1)}$.

I entered graduate school in economics, specializing in labor economics to try to understand why the supposedly richest nation on earth had significant and persistent poverty. I wrote my doctoral dissertation on working conditions in the bituminous mining industry, witnessing first-hand the crude thirst for wealth; and how workers, rather than participating in a joint endeavor, were "interchangeable parts in the production process" (Zaman, 2018, p. 84).

I agree with Zaman's big picture in his article and most of his minor points, so I have little to impugn. Given my interest in sustainability and economics education, I will focus my comments two-fold:

(1) actualizing Asad's suggestions in order to move forward so we can create and implement sustainability;

(2) integrating his suggestions into the broader movement to Rethink and Reconceptualize Economics, in order to effectuate a broadbased policy.

Being asked to comment on an Islamic approach to poverty and inequality, I should mention that I am not an expert on Islamic economics, although I have read extensively on the subject. And I should mention that I am a Roman Catholic. But I have read the Qur'ān and have been impressed by its beauty, wis-

(1) Also, crucial for fostering inequality is the deliberate creation of race, which unfortunately has been a central factor in American history. Alexander (2012) gives a rich and interesting history. This is in sharp contrast to Islam where the "extinction of race consciousness as between Muslims is one of the outstanding achievements of Islam" Arnold Toynbee as quoted in Zaman (2018, p. 81). dom, compassion, and justice. I appreciate its inviting kindness in embracing non-Muslims. And as a person who wants to do good, but never feels he is doing enough, I take solace from the following verse:

whoever saves one (life), it is as if he had saved the entire mankind. (Qur'ān, 5:32)

\section{Capitalism and Sustainability: Never the Twain Shall Meet}

Thomas More's novel, Utopia (1516) envisioned a blissful society without poverty: a mythical society without money, unemployment or private property, in which,

[E]verything's under public ownership, no one has any fear of going short, as long as the public storehouses are full. Everyone gets a fair share, so there are never any poor men [sic] or beggars. Nobody owns anything, but everyone is rich - for what greater wealth can there be than cheerfulness, peace of mind, and freedom from anxiety? (More, 1516/1965, p. 128)

In imagining a world without poverty, More by naming his mythical island Utopia, suggests how ubiquitous and intransigent poverty really is. It has existed in all societies. So why has the west failed to understand its nature and devise effective solutions? Why does poverty still exist and why do we tolerate it? Since economics is defined as the study of how we provision, does the persistence of poverty suggest the failure of economic theory?

At least for me, Henry George hit the nail on the head, writing more than 150 years ago,

Discovery upon discovery, and invention after invention, have neither lessened the toil of those who need most respite, nor brought plenty to the poor ... From all parts of the civilized world come comp-laints of industrial depression; of labor condemned to involuntary idleness; of capital massed and wasting ... All the dull, deadening pain, all the keen, maddening anguish, that to great masses of men [sic] are involved in the 'hard times', afflict the world today. (George, 1879/1948, pp. 5-6).

And, despite spectacular increases in overall wealth, as Sen (1999) writes,

We live in a world of unprecedented opulence, of a kind that would have been hard even to imagine a century or two ago ... And yet we also live in a 
world with remarkable deprivation, destitution and oppression ... Overcoming these problems is a central part of the exercise of development. (p. xi)

Many critics of capitalism agree with George that a systemic reason exists for the production of poverty amidst plenty, "as though an immense wedge were being forced, not underneath society, but through society. Those who are above the point of separation are elevated, but those who are below are crushed down" (George, 1879/1948, p. 9). For Marx, of course, the 'wedge' was caused by the separation of classes into workers and capitalists and the drive to accumulate, leading to exploitation and the creation of surplus value. But why does capitalism continue to produce both progress and poverty? And why, after 150 years, does this 'wedge' persist? Of course, as Zaman (2018) quotes from Stavrianos, "states of developedness and under-developedness are but two sides of the same coin" (p. 72). Capitalism produces both wealth and poverty and each is necessary for the other.

Capitalism is defined as the private ownership of the means of production. Its modus operandi is accumulating wealth in order to maximize profits: "the pursuit of wealth the most important goal" (Zaman, 2018, p. 77). Capitalism (along with its lackey, neoclassical economics) developed during an age when resources were relatively plentiful, when

economists thought, wrote, and prescribed as if nature did not [exist] ... The growth fetish, while on balance quite useful in a world with empty land, shoals of undisturbed fish, vast forests, and a robust ozone shield, helped create a more crowded and stressed one. (McNeil, 2000, pp. 335-336).

Property rights are central to capitalism: A property right "is a relationship between the rights holder and the rights regarders under a specific authority structure like the state granting legitimacy and security to a specific resource or benefit stream" (Vatn, 2005, p. 254). In other words, a right to own property is a social relation conceptualized, defined and protected by the state. The state has a clear role in defining and enforcing a property right and since the converse of the right to own is the right to exclude, the state defines and enforces the right to exclude. And, since the right is a social relation and social relations change, so do property rights.
Capitalism has significantly increased productivity while reducing the marginal cost of producing many goods to near zero; a situation which will intensify in the near future. The combination of 3D printing and automation is changing the very concepts of the firm, consumer, industry, and the meaning of work. The commons is becoming more important vis-à-vis the market resulting in greater expectations for sharing (its modus operandi) rather than exchange (the modus operandi for markets). Jeremy Rifkin (2014) wrote that
Markets are beginning to give way to networks, ownership is becoming less important than access, the pursuit of self-interest is being tempered by the pull of collaborative interests, and the traditional dream of rags to riches is being supplanted by a new dream of a sustainable quality of life. (p. 19)

And, it is obvious that power is central to property rights and to capitalism, an issue actively discussed by classical economics but "routinely neglected" (Zaman, 2018, p. 87) by neoclassical economists; power is conspicuously absent in neoclassical textbooks. Accumulating surpluses characterizes all societies, including capitalist ones,
there is no reason why a surplus must exist, but it does exist and has existed in all but a few human societies. The surplus may be used in a variety of ways. It can take the form of cathedrals, palaces, luxury goods, military spending, more and better productive equipment, higher levels of education, improved health, and many other things. The surplus product is a powerful lens that can help us understand how a society works. (Bowles, Edwar- ds, \& Roosevelt, 2005, pp. 93-94).

Capitalism is distinguished by using its surplus to further profits and accumulate additional surplus in order to make more surplus. It is a never-ending cycle, of which much has been written. It is this drive to accumulate that forces capitalism to create "the need of a constantly expanding market for its products chas[ing] the bourgeoise over the whole surface of the globe. It must nestle everywhere, settle everywhere, establish connections everywhere" (Marx \& Engels, 1848/1992, p. 8).

Zaman distinguishes capitalism from more traditional societies in which the surplus was used to form and bond communities so that the wealthier were able to care for the poor: "all those with resou- 
rces in excess of their needs are collectively responsible for those who do not have sufficient resources" (Zaman, 2018, p. 82).

Given capitalism's salient features, it is unreasonable to assume capitalism's ability to solve the looming environmental crisis. Capitalism is incapable of rectifying itself; its inner logic of inexorable capital accumulation will doom it (and us) to an ecological collision (Reardon, Madi, \& Cato, 2017, p. 334).

Capitalism, with its profit-driven firms, assumes citizens are competitive. This can have damaging social consequences as countries compete to reduce wages and employment standards and consumers engage in consumption-based competition that threatens their psychological well-being. Capitalism also begets inequality given that competition produces losers and winners. Perhaps most importantly, the very benefits claimed for market systems - their dynamism and compulsion to create innovation and economic growth - lead us to interpret progress in narrow human terms, ignoring ecological limits and the carrying capacity of our world (Reardon et al., 2017, p. 172).

Capitalism's salient characteristics do not comport with the United Nations' 17 Sustainable Development Goals (SDGs), issued in 2015, to provide the contours for a sustainable society (United Nations, 2015):

1. End poverty in all its forms everywhere.

2. End hunger, achieve food security and improved nutrition, and promote sustainable agriculture.

3. Ensure healthy lives and promote well-being for all at all ages.

4. Ensure inclusive and equitable quality education and promote lifelong learning opportunities for all.

5. Achieve gender equality and empower all women and girls.

6. Ensure availability and sustainable management of water and sanitation for all.

7. Ensure access to affordable, reliable, sustainable and modern energy for all.
8. Promote sustained, inclusive and sustainable economic growth, full and productive employment and decent work for all.

9. Build resilient infrastructure, promote inclusive and sustainable industrialization and foster innovation.

10. Reduce inequality within and among countries.

11. Make cities and human settlements inclusive, safe, resilient and sustainable.

12.Ensure sustainable consumption and production patterns.

13. Take urgent action to combat climate change and its impacts.

14. Conserve and sustainably use the oceans, seas and marine resources for sustainable development.

15. Protect, restore and promote sustainable use of terrestrial ecosystems, sustainably manage forests, combat desertification, and halt and reverse land degradation and halt biodiversity loss.

16. Promote peaceful and inclusive societies for sustainable development, provide access to justice for all, and build effective, accountable and inclusive institutions at all levels.

17. Strengthen the means of implementation and revitalize the Global Partnership for Sustainable Development

Notice the wording: 'all', inclusive', and 'urgent'; and the active verbs: end, ensure, achieve, promote, reduce, conserve, revitalize. This is the language of the SDGs; this is the language of urgency (Reardon et al., 2017, p. 18). But it is not the language of capitalism. Capitalism and sustainability are on a collision course. Central to the SDGs and the essence of sustainability, and conspicuously absent in both capitalism and neoclassical theory, is a foundational ethics. No need; since the market equilibrates supply and demand allocating a just wage to all factors of production. But sustainability, with its focus on equity and justice, must be based on ethics. Given that capitalism has caused and exacerbated poverty and inequality, it is foolish to look within it for a solution; as it is foolish to look within capitalism for a solution to climate change. 


\section{Actualizing Zaman's Suggestions}

(1) Zaman writes, "spiritual and social arrangements must be supplemented by complementary institutional and legal frameworks in order to have an effective impact on real-world problems" (p. 81). Agreed. And later: "In order to impact the real world, the spirit of generosity, compassion, and responsibility, strongly embodied in the teachings of Islam, must be given concrete expression in the form of institutional structures for implementation" (p. 85). Agreed; but easier said than done.

Suggestion: One way to implement 'institutional and legal frameworks' is to conduct workshops, exchange faculty/students, guest lectures between and among faculty, students, and policy makers, discussing the practical solutions Islam can offer. Dialogue, especially in a context of pluralism, is crucial.

(2) Whereas capitalism and neoclassical economics encouraged individualism separate from an effective community, any transition to sustainability will necessitate both collective consciousness and collective action, missing in today's capitalism but ubiquitous in Islam, "the message of Islam is to unite all of humanity under the banner of the best ideals in the common heritage of mankind" (Zaman, 2018, p. 81).

Suggestion: Western capitalist nations cannot conceive of an effective community, which is a strong suit of Islam, and given the Qur'ān's kind view of nonMuslims, Islam has a lot of practical suggestions to create and welcome a community.

(3) Given the widespread near-zero cost of producing many goods/services and the concomitant threat of automation, the notion of basic income is important. As Zaman argues, "economic security also frees individuals to turn to higher spiritual and social pursuits" (p. 82). Is it quixotic to think/assume that if every nation implemented a basic income ${ }^{(2)}$, possibly we

(2) Guy Standing (2017, p. 3) defines basic income as: "a modest amount of money paid unconditionally to individuals on a regular basis... It is often called a universal basic income (UBI) because it is intended to be paid for all". Standing provides a comprehensive and easily accessible discussion of basic income, and provides suggestions to incorporate a basic income pilot and initiative, along with extensive references. He argues (quite convincingly) that a basic income strengthens basic freedoms, especially "To refuse a job that is onerous and boring, low-paying or just nasty, ... [and] to do care work for a relative or friend, or voluntary work in and for the community, that might not be feasible if financial necessity required long hours of paid labour" (pp. 60-61). could turn our attention toward higher spiritual and social pursuits? Couldn't this be the basis of a common pursuit of sustainability? Could a basic income be an effective and sustainable solution to make work both fulfilling and meaningful? A basic income would attenuate the 'social exclusion' problem that Zaman referred to earlier (pp. 77-78). A basic income is inevitable and will be the basic foundation for a sustainable economy:

By freeing up individuals from having to labour in the market, basic income allows for active work in the commons and social sectors, which today are hardly considered, or even measured, as worthwhile economic objectives. By shifting attention away from paid labour, which today is largely underwritten by cheap availability of fossil fuels, and deductions, subsidies and giveaways in the tax code, a basic income can attenuate climate change while also redirecting us away from ever-increasing and unsustainable consumption. (Reardon et al., 2017, p. 110)

Suggestion: Advocate for a basic income; this is a growing (and at least in my opinion) inevitable movement which will create and foster global networks.

(4) We have today a palpable inequality between nations in terms of wealth and power (both hard and soft). As Zaman argues, Islam has a rich his-tory of the existence of inequality as the basis for cooperation and understanding between individuals; likewise, inequality between nations can and should provide for a community of nations. Is the nation the most efficacious entity in achieving sustainability? And given that capitalist society is "composed of individuals pursuing separate and conflicting goals" (p. 82), what exactly and who does the state represent?

Suggestion: Perhaps Islam can reach out to climate talk negotiators about the cooperation based on inequality and the reciprocity between rich and poor nations, building on Zaman's important statement,

Whereas poverty and inequality are social problems in a capitalistic society, they are tools to build community in an Islamic society ... Inequalities and poverty create dependencies and complementarities where each person has something that other's need and also has needs for which he must turn to the community. This network of needs and dependencies acts as a lubricant in the creation of cooperation and community. (pp. 78-79) 
(5) I fully agree with Zaman's assertion that "a major source of poverty and inequality today is lack of access to equal opportunities to education ... . [and] even more important . . . is the failure to provide the right kind of education" (p. 83). Zaman contrasts this failure with the universal access to education in precolonization Islamic societies. Being most familiar with economics education here in the west, what passes for education isn't education - preparing students to understand our world - but proselytization: forcing students to think a certain way, as if there was only one way. Consider the lamentation of the authors of the influential The Econocracy:

Having graduated now we are all keenly aware that our economics education has not equipped us with the knowledge or skills to justify any authority are given. In fact, we were so frustrated with how little our education was helping us understand the world that midway through our second year at university we began a campaign to reform economics education. (Earle, Moran, \& Ward-Perkins, 2016, p. 2)

Capitalism and economics has "rarely been at 'scientific' arm's length; they have always been incestuous to some degree, and most shamelessly as we approach the present" (Dowd, 2004, xiii). The same can be said for economics education. Not only do neoclassical economists assume, rather than empirically investigate, that capitalism naturally gravitates toward equilibrium, but that this equilibrium is as good as it gets. The danger is that the model is confused with reality and, more importantly, that the ideology prevents understanding of how our world really works.

Zaman writes that "the brutal and sordid process of colonization required the development of brutal ideologies which tolerate, and even celebrate, luxurious lifestyles of the rich and powerful in presence of stark misery of billions" (p. 88). Indeed, this has been (and is) the role of neoclassical economics; it is also why economics remains an obstacle in conceptualizing more equitable ways of provisioning. Economics and economics education is overflowing with "mythical justifications" (Zaman, 2018, p. 73). Rod Hill and Tony Myatt (2010) write that economics textbooks "often present hypotheses and policy prescriptions with surprisingly little or no supporting evidence, or (worse) they ignore inconvenient contrary evidence" (p. 6). If education "is the route to equal opportunity" (Zaman, 2018, p. 83) then economics has massively failed ${ }^{(3)}$.

As an MBA teacher myself, I agree with Zuboff's comment that, "much of what my colleagues and I taught has caused real suffering, suppressed wealth creation, destabilized the world economy, and accelerated the demise of the $20^{\text {th }}$ century capitalism" (Zaman, 2018, p. 86, note 17). Perhaps in my own defense, MBA teachers with pluralist and sustainable values (almost an oxymoron, however, especially here in the US) can make a difference, albeit within a narrow limit of allowable capitalism criticism. It is the textbooks that, at least in my view, present a more formidable problem. Here's one example from a leading managerial economics textbook,

Making money is simple in principle - find an asset employed in lower-valued use, buy it, and then sell it to someone who places a higher value on it. The one lesson of business: the art of business consists of identifying assets in low-valued uses and devising ways to profitably move them to highervalued ones. (Froeb, Shor, McCann, \& Ward, 2017, p. 18)

Bothersome is that this is presented to students as the number one lesson, without any specific counsel on who determines the value and the price; and obscured, of course, is existence and use of underlying power. But at the same time, more students are concerned about the collision of sustainability and capitalism and what they can do; and more students are working for non-profit companies.

Suggestion: Directly reach out to student-led groups Rethinking Economics and its affiliates in order to provide and attain additional support.

(6) Economics is currently contested. Witness the movement underway to rethink and reconceptualize economics. Even the very definition of economics is contested, with neoclassicals preferring a means/end definition that highlights method (and a highly ideological one at that) rather than subject matter. Heterodox economists prefer to define economics as

(3) Edward Fullbrook (2009) wrote during the most recent financial crisis, "Because of human error propagated by a virulent ideology skillfully camouflaged as science, millions of American families are losing their homes, 100 million people in the world stand to lose their jobs and a generation has been deprived of the hope it deserves" (p. 22). 
about "provisioning, or how societies organize themselves to sustain life and enhance its quality" (Nelson, 2009, p. 61).

How a discipline defines itself determines its subject purview, research objectives, and pedagogy. The means/end definition gratuitously elevates scarcity to center stage; and it is the crux of neoclassical pedagogy, gratuitously offered as a cause for just about every problem, including poverty. Zaman notes that it is "false and misleading" to offer scarcity as the cause of poverty when more realistically it is "misuse of existing wealth and material possessions which leads to poverty and inequality" (p. 87).

Suggestion: Embracing the provision definition of economics will increase the acceptability of the Islamic ideas of poverty and inequality.

(7) Zaman writes that "poverty is a multidimensional phenomenon" (p. 78). Agreed. Neo-classical economics fails to conceptualize poverty in its multidimensional forms, which has stifled thinking about both causes and solutions. But then again, this is true about every issue that neoclassical economics tackles: unemployment, investment, consumption, climate change, pollution, etc. Neoclassical economics presents what should be a complex issue as a single dimension, which often confuses students since the presentation is overly deductive and anti-historical. Not only do we need a new economic system, but we need a new economics - a reconceptualized economics that looks to the future for inspiration, that includes rather than excludes, that denies there is only one truth, that encourages and welcomes diversity.

Neoclassical economics measures poverty as an absence of income (either absolute or relative). But the income earned also determines the extent of participation in the economy; and without income one is excluded from participation. This notion of "social exclusion is a very important dimension of poverty, neglected in simple-minded approaches which view poverty as merely a lack of money" (Zaman, 2018, p. 77). It is also neglected (or overlooked) in neoclassical economics. As one example:
Techniques such as contingent valuation used to measure the costs and benefits of environmental policies $^{(4)}$ assume one has money (ability to pay). The technique is used in order to either ascertain one's willingness to pay to retain a benefit or receive money for the loss; but an individual without an income or living in poverty is by definition excluded from participating. So, within the already convoluted world of neoclassical economics, social exclusion convolutes policy even more by constricting the determination of the requisite Pigouvian tax to correct an externality to those with the ability to pay, which further biases an already biased outcome.

A better conceptualization of poverty and one that comports with Islamic insights is 'the capability approach', which shifts focus away from means (income and wealth) toward ends (reaching one's potential) and the freedom to satisfy those ends (Sen, 1999, p. 87). The capability approach gets right to the heart of the matter by ascertaining an individual's capability to live a full and meaningful life. The main problem, however, is that this is far more difficult to measure than the income approaches; but that doesn't mean we should embrace the simplest methods, regardless of its realism. The capability approach is far more amenable to incorporating the "vital social and spiritual aspects, which can be both part of the problem and part of the solution" (Zaman, 2018, p. 87).

Suggestion: scrap the absolute and relative measures of poverty (widely used throughout the world) in favor of Sen's capability approach - the framework is in place.

Suggestion: Ascertain the use of power currently in all its dimensions which in turn will help us understand the obstacles to achieving an equitable transition to sustainability. Power, vested interests, and lock-in commitment are necessarily important to understand our world and how to make it more equitable. Understanding power and its use allows us to understand how/why the true causes/solutions of poverty have been deliberately obscured. This is a natural segue into collaboration with the Rethinking Economics movement.

(4) For an explanation of these techniques see Harris and Roach, 2018. 


\section{Conclusion}

Alfred Marshall, in the eighth edition of his Principles of Economics, wrote that "economic conditions are constantly changing, and each generation looks at its own problems in its own way" (Marshall, 1890/ 1946, p. v). Our generation is beset with many problems including climate change, a global financial crisis, a palpable disparity in income and wealth, and a health care crisis. These problems are mutually reinforcing and will only worsen. At the center, however, is the discipline of economics itself and economics education, which obfuscates the interrelationship of our problems, inures its students to human suffering and abnegates thoughtful discussion of the human predicament.

Given capitalism's salient characteristics and its track record, it is nonsensical to suggest solutions for poverty and inequality from within capitalism itself (just as it is nonsensical to suggest market solutions for climate change). We must devise other solutions,

\section{References}

Alexander, M. (2012). The New Jim Crow: Mass Incarceration in the Age of Colorblindness. New York: The New Press.

Bowles, S., Edwards, R., \& Roosevelt, F. (2005). Understanding Capitalism: Competition, Command and Change (3rd ed.). New York: Oxford University Press.

Dowd, D. (2004). Capitalism and its Economics: A Critical History. London: Pluto Press.

Earle, J., Moran, C., \& Ward-Perkins, Z. (2016). The Econocracy: The Perils of Leaving Economics to the Experts. Manchester, UK: University of Manchester Press.

Froeb, L., Shor, M., McCann, B., \& Ward, M. (2017). Managerial Economics: A Problem-Solving Approach (5th ed.). Boston: Cengage.

Fullbrook, E. (2009). The Meltdown and Economics Textbooks. In J. Reardon (Ed.), The Handbook of Pluralist Economics Education (pp.17-23). London: Routledge.

George, H. (1948). Progress and Poverty. New York: Robert Schalkenbach Foundation. (Original work published in 1879). and I enthusiastically endorse Zaman's conclusion to look at Islam:

It is true that the rich and multi-dimensional set of solutions offered to problems of the poverty and inequality by the Qur'ān is far better than anything currently available... The conceptual framework it offers remains revolutionary and offers solutions to deep and difficult problems currently facing humanity. It remains to be seen whether Muslims can shoulder the burden of responsibility placed upon them to serve as beacons of guidance for the world to follow. (p. 88)

It also remains to be seen if western capitalist nations can also share the burden by reaching out, understanding and cooperating with their fellow human beings. I will work hard to implement these suggestions as well as conduct workshops and networking to increase global cooperation. Time is urgent: Our window of opportunity is rapidly closing.

Harrington, M. (1997). The Other America: Poverty in the United States. New York: Simon and Schuster. (Original work published in 1962)

Harris, J., \& Roach, B. (2018). Environmental and natural resource economics: a contemporary approach (4th ed.). London: Routledge.

Hill, R., \& Myatt, T. (2010). The Economics AntiTextbook: A Critical Thinker's Guide to Microeconomics. London: Zed Books.

Islahi, A. A. (2014). History of Islamic Economic Thought: Contributions of Muslim Scholars to Economic Thought and Analysis. Cheltenham, UK: Edward Elgar.

Marshall, A. (1946). Principles of Economics (8th ed.). London: Macmillan. (Original work published in 1890).

Marx, K., \& Engels, F. (1992). The Communist Manifesto. Oxford, UK: Oxford University Press. (Original work published in 1848).

McNeil, J. R. (2000). Something New Under the Sun: An Environmental History of the Twentieth-century World. New York: Norton.

More, T. (1965). Utopia (P. Turner, Trans.). New York: Penguin Books. (Original work published in 1516). 
Nelson, J. (2009). The Principles Course. In J. Reardon (Ed.), The Handbook for Pluralist Economics Education (pp.57-68). London: Routledge.

Reardon, J., Madi, M., \& Cato, M. S. (2017). Introducing a New Economics: Pluralist, Sustainable and Progressive. London: Pluto Press.

Rifkin, J. (2014). The Zero Marginal Cost Society: The Internet of Things, the Collaborative Commons, and the Eclipse of Capitalism. New York: Palgrave Macmillan.

Sen, A. (1999). Development as Freedom. New York: Anchor Books.

Standing, G. (2017). Basic Income: And How We Can Make it Happen. London: Pelican Books.
United Nations. (2015). Sustainable Development Goals. Retrieved from: https://sustainabledevelopment.un. org/?menu=1300

Vatn, A. (2005). Institutions and the Environment. Cheltenham, UK: Edward Elgar.

Zaman, A., \& Reardon, J. (2015). Foreword [Special Issue on the Challenge of Islamic Economics]. International Journal of Pluralism and Economics Education,6(4), 313-323.

Zaman, A. (2018). An Islamic Approach to Inequality and Poverty. Journal of King Abdulaziz University: Islamic Economics, 31(1), 69-92.

Jack Reardon is the Chief Editor of the International Journal of Pluralism and Economics Education. He teaches economics in the School of Business at the Hamline University, USA. His research interests include economics education, energy and the environment, and labor economics. He has published in a wide variety of journals including the Journal of Economic Issues, Monthly Labor Review and International Journal of Green Economics. He has published A Handbook for Pluralist Economics Education (Routledge) and The Economics Curriculum: Towards a Radical Reformulation (World Economics Association Books). His work on principles of economics textbook entitled Introducing a New Economics: Pluralist, Sustainable and Progressive was recently published by Pluto Press.

E-mail: jreardon02@hamline.edu; jackreardon864@gmail.com 


\title{
إعادة تصور وإعادة النظر في علم الاقتصهاد للقضاء على عدم المساواة والفقر
}

\author{
جاك رياردن \\ أستاذ الاقتصاد، جامعة هاملين، مينيسوتا، الولايات المتحدة الأمريكية
}

المستخلص. مظاهر الفقر في المدن الداخلية والمناطق الريفية في أمريكا "الغنية" أمر مروع بالنسبة

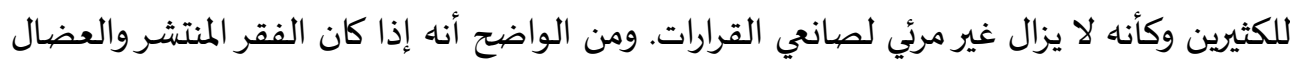

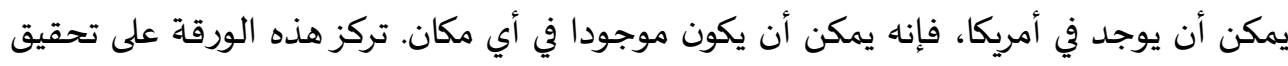

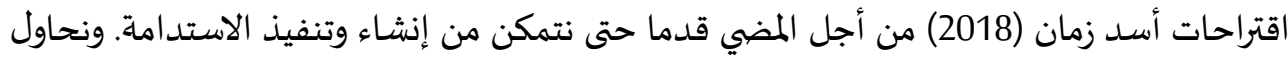

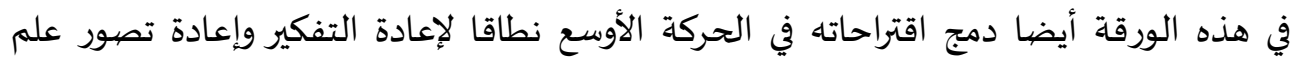
الاقتصاد من أجل وضع سياسة عريضة القاعدة للقضاء على مشكلتي عدم المساواة والفقر. 